(C) 2014

Тарасенко Л. О., доктор ветеринарних наук

Одеський державний аграрний університет

\title{
ЕФЕКТИВНІСТЬ ЗАСТОСУВАННЯ КОРМОВОЇ ДОБАВКИ ПЕКТИНОВМІСНОӤ ПОРОСЯТАМ НА ДОРОЩУВАННІ
}

\section{Рецензент - доктор ветеринарних наук, професор М. П. Високос}

Дослідженнями доведено, щуо застосування кормової добавки пектиновмісної поросятам на дорошуванні за оптимальної дози 0,3 г/кг живої маси впродовж 30-ти діб для зменшення вмісту кадмію, купруму, плюмбуму $і$ меркурію в усіх органах $і$ тканинах до рівнів ГДК позитивно вплинуло на нормалізацію метаболічних процесів, рівень мінерального та білкового обміну, покращзання морфологічного складу крові. Відома залежність активності ферментів від наявності в реакційній суміші активаторів і інгібіторів. Саме механізм зниження активності названих складних ферментів можливо пояснити наявністю інгібіторів речовин, які викликають гальмування реакиій, щуо каталізуються ферментами, в ролі яких у даному випадку виступають важкі метали, виведення яких у разі застосування пектиновмісної кормової добавки нормалізують ферментативні процеси.

Ключові слова: кормова добавка пектиновмісна, кадмій, купрум, плюмбум, меркурійметаболічні прочеси, морфологічний склад крові, мінеральний, білковий обмін.

Постановка проблеми. Останнім часом у ветеринарній науці й практиці значна увага приділяється контролю за здоров'ям тварин, санітарному стану територій та одержанню продукції високої якості. Однак в окремих регіонах України склалася складна екологічна ситуація, що призводить до зниження санітарної якості продукції тваринництва, яка надходить на переробні підприємства або використовується як харчові продукти [2].

Аналіз останніх досліджень i публікацій, у яких започатковано розв'язання проблеми, свідчить, що серед основних речовин-забруднювачів довкілля основне місце посідають хімічні елементи, які відносяться до групи важких металів і створюють найбільшу небезпеку для тварин і людей $[1,3]$. Тому актуальним $\epsilon$ впровадження ефективних природних засобів із метою зниження негативної дії токсикантів на організм тварин i покращання якості продукції в екологічному відношенні.

Мета і завдання досліджень. Метою досліджень було визначити дію кормової добавки пектиновмісної на інтенсивність виведення важких металів $з$ органів і тканин, рівень метаболічних процесів, мінеральний та білковий обмін в організмі поросят на дорощуванні.

Для досягнення мети було позначено наступні завдання:

- визначити вміст важких металів в органах $\mathrm{i}$ тканинах поросят та порівняти 3 гранично допустимою концентрацією;

- визначити інтенсивність виведення важких металів за дії кормової добавки пектиновмісної на 1-шу, 15-ту, 30-ту добу досліджень;

- дати оцінку дії кормової добавки пектиновмісної, рівень метаболічних процесів, мінеральний та білковий обмін.

Матеріал і методи. Матеріалом для проведення досліджень були зразки крові, екскрементів, органів і тканин поросят на дорощуванні. Вміст важких металів (кадмій, купрум, плюмбум, цинк, меркурій) у відібраних зразках визначали методом інверсійної вольтамперометрії на приладі АВА-2 після попередньої мінералізації за допомогою «Темос-експреса».

Результати дослідження. Дослідження проводили на поросятах української великої білої породи (на дорощуванні) по 20 голів у контрольній i дослідній групах, живою масою 25 кілограмів. Поросятам контрольної групи згодовували основний раціон, поросятам дослідної групи - основний раціон із додаванням кормової добавки пектиновмісної у дозі 0,3 г/кг живої маси впродовж тридцяти діб.

Контроль інтенсивності виведення важких металів 3 організму поросят у разі застосування кормової добавки пектиновмісної проводили на $1-y, 15-$ у та 30-у добу шляхом відбору зразків тканин і паренхіматозних органів у забитих поросят контрольної та дослідної груп. Накопичення важких металів у нирках поросят представлено в таблиці 1.

Одержані результати досліджень свідчать, що вміст кадмію в нирках поросят дослідної групи в 1-у, 15-у добу застосування пектиновмісної кормової добавки перевищував гранично допустиму концентрацію, відповідно, у 18,3; 9,6 рази, на 30-у добу був у межах норми. 
ВЕТЕРИНАРНА МЕДИЦИНА

\section{1. Вміст ваэкких металів у нирках поросят за згодовування пектиновмісної кормової добавки,} мг/кг $(M \pm m, n=3)$

\begin{tabular}{|c|c|c|c|c|c|c|}
\hline \multirow{3}{*}{ 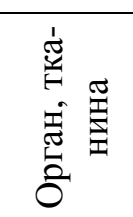 } & \multirow{3}{*}{ 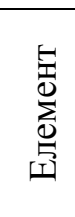 } & \multicolumn{5}{|c|}{ Період досліджень, діб } \\
\hline & & 1 & 15 & 30 & 1 & 30 \\
\hline & & \multicolumn{3}{|c|}{ дослідна група } & \multicolumn{2}{|c|}{ контрольна група } \\
\hline \multirow{4}{*}{ Нирки } & $\mathrm{Cd}$ & $\begin{array}{c}0,916 \pm \\
0,065\end{array}$ & $\begin{array}{l}0,48 \pm \\
0,067\end{array}$ & $\begin{array}{c}0,017 \pm \\
0,002\end{array}$ & $\begin{array}{l}0,62 \pm \\
0,040\end{array}$ & $\begin{array}{l}0,70 \pm \\
0,067\end{array}$ \\
\hline & $\mathrm{Cu}$ & $\begin{array}{c}4,17 \pm \\
0,45\end{array}$ & $\begin{array}{c}3,02 \pm \\
0,38\end{array}$ & $\begin{array}{c}0,621 \pm \\
0,081\end{array}$ & $\begin{array}{c}4,64 \pm \\
0,07\end{array}$ & $\begin{array}{c}8,74 \pm \\
0,12\end{array}$ \\
\hline & $\mathrm{Pb}$ & $\begin{array}{l}0,22 \pm \\
0,033\end{array}$ & $\begin{array}{c}0,122 \pm \\
0,017\end{array}$ & $\begin{array}{c}0,104 \pm \\
0,06\end{array}$ & $\begin{array}{c}0,20 \pm \\
0,03\end{array}$ & $\begin{array}{l}0,23 \pm \\
0,033\end{array}$ \\
\hline & $\mathrm{Zn}$ & $\begin{array}{c}14,3 \pm \\
0,48\end{array}$ & $\begin{array}{c}13,04 \pm \\
0,22\end{array}$ & $\begin{array}{l}9,7 \pm \\
3,39\end{array}$ & $\begin{array}{c}14,60 \pm \\
0,27\end{array}$ & $\begin{array}{c}19,8 \pm \\
0,71\end{array}$ \\
\hline
\end{tabular}

У контрольній групі зазначений показник на 1-у та 30-у добу перевищував ГДК у 12 та 14 разів відповідно. Вміст купруму, плюмбуму та цинку був у межах ГДК, що свідчить про антагоністичну дію кадмію по відношенню до зазначених елементів.

Аналіз цих даних свідчить про те, що застосування пектиновмісної кормової добавки на 30-у добу досліджень позитивно вплинуло на інтенсивність виведення кадмію з нирок поросят дослідної групи, на що вказує зменшення рівня останнього у 8 раз, однак залишковий вміст токсиканта перевищував ГДК у 2,34.

Дослідженнями доведено, що вміст міді й цинку в печінці поросят контрольної та дослідної груп на 30-у добу досліджень відповідав встановленому гранично допустимому рівню, вміст кадмію та свинцю перевищував гранично допустимі рівні у 1,3 та 3,74 рази відповідно в контрольній групі, у дослідній групі мав помірні концентрації за весь період досліду й тенденцію до зменшення.

Встановлено, що на 30-у добу досліджень уміст усіх елементів у печінці поросят дослідної групи знаходився в межах ГДК.

Одержані результати досліджень свідчать, що вміст міді та цинку у селезінці поросят контрольної та дослідної груп упродовж усього періоду досліджень був у межах ГДК. Вміст кадмію у селезінці поросят контрольної групи впродовж усього досліду перевищував ГДК і мав тенденцію до збільшення. Дослідженнями встановлено, що в селезінці поросят дослідної групи вміст кадмію та свинцю на першу добу досліджень перевищував ГДК у 3,9 та 4,05 рази відповідно, на 15-у добу застосування пектиновмісної кормової добавки перевищення відносно ГДК ста- новило 3,7 та 3,1 рази відповідно, що вказує на зниження рівня токсиканту. На 30-у добу досліджень вміст кадмію та свинцю в селезінці поросят дослідної групи зменшився до рівнів ГДК.

Фоновий рівень кадмію в серцевому м'язі поросят дослідної групи у 1 -у та 15 -у добу досліджень перевищував ГДК у 3,46 та 1,82 рази, контрольної - у 1,98 та 4 рази відповідно. Вміст даної сполуки в зазначених зразках поросят дослідної групи на 30-у добу застосування пектиновмісної кормової добавки зменшився до рівня ГДК.

Вміст міді й цинку у серцевому м'язі поросят контрольної та дослідної груп був у межах ГДК. Рівень свинцю у серцевому м'язі поросят дослідної групи мав помірні концентрації, контрольної тенденцію до збільшення і на 30-у добу перевищував ГДК учетверо.

Одержані результати досліджень свідчать, що вміст кадмію в жировій тканині поросят дослідної групи в 1 -у та 15 -у добу застосування пектиновмісної кормової добавки перевищував ГДК у 1,6 та 1,2 рази, на 30 -у добу зменшився до мінімальних рівнів і відповідав ГДК. Встановлено, що в контрольній групі у зазначених зразках дана сполука інтенсивно накопичувалася 3 1-ї до 30-ї доби, перевищуючи встановлені гранично допустимі рівні у 3,2 та 3,4 рази відповідно. Вміст свинцю в жировій тканині поросят контрольної та дослідної груп був у верхній межі ГДК, але в зразках тканини поросят контрольної групи на 30-у добу спостерігалося збільшення даної сполуки порівняно 3 1-ю добою досліду, рівень міді та цинку був нижчим порівняно 3 ГДК.

Встановлено перевищення вмісту кадмію в м'язовій тканині поросят контрольної та дослід- 


\section{ВЕТЕРИНАРНА МЕДИЦИНА}

ної групи у першу добу досліджень у 1,34 та 1,52 рази відповідно.

Застосування пектиновмісної кормової добавки поросятам дослідної групи сприяло зменшенню даної сполуки на 15 -у добу у 1,2 рази й на 30 -у добу вдвічі, порівняно з першою, до меж ГДК.

У контрольній групі зазначені процеси спостерігалися в бік збільшення накопичення токсиканта в м'язовій тканині й перевищували ГДК у 1,8 разу на 30 -у добу досліджень. Рівень свинцю в м'язовій тканині поросят контрольної групи перевищував ГДК на 1-у та 30-у добу досліджень у 1,6 і 1,3 рази.

Відомі наступні шляхи виведення токсикантів 3 організму: через нирки 3 сечею, шлунковокишковий тракт із фекаліями і незначна частина - в процесі видихання через легені.

3 метою визначення шляхів виведення важких металів з організму поросят було відібрано екскременти у дослідних тварин, проведено підготовку зразків і методом інверсійної вольтамперометрії досліджено вміст важких металів у сечі і фекаліях. Результати досліджень свідчать про можливість пектинових речовин у кишечнику адсорбувати важкі метали, зв' язувати їх у нерозчинні комплекси й виводити 3 організму з екскрементами.

Встановлено, що більш ефективно діють пектинові речовини на виведення кадмію через нирки поросят із сечею, а також через шлунковокишковий тракт із фекаліями. Так, на 15 -у добу $15,87 \%$ кадмію виведено з фекаліями і 31,27 - із сечею; 5,8\% свинцю виведено 3 фекаліями та $23,8 \%$ - із сечею; $35,76 \%$ міді виведено з сечею, 20,68 - із фекаліями. Різниця між першою й п'ятнадцятою добою згодовування кормової добавки за всіма елементами крім цинку в сечі вірогідна $\mathrm{P} \geq 0,999$, а в фекаліях за цинком $\mathrm{P} \geq 0,99$.
Різниця між 15-ю і 30-ю добою за вмістом усіх елементів, що вивчали, (крім міді) в фекаліях і сечі вірогідна $\mathrm{P} \geq 0,999$.

Різниця між 1-ю і 30-ю добою згодовування пектиновмісної кормової добавки за всіма досліджуваними елементами в фекаліях і сечі поросят, вірогідна $\mathrm{P} \geq 0,999$, окрім кадмію.

Встановлено, що застосування пектиновмісної кормової добавки впродовж 30-ти діб поросятам дослідної групи сприяло виведенню важких металів: кадмію, свинцю, міді з організму тварин до рівнів ГДК.

Згодовування поросятам кормової добавки пектиновмісної позитивно вплинуло на нормалізацію білкового та мінерального обміну, рівень метаболічних процесів (табл. 2).

Так, нами доведено, що на 30-у добу дослідження активність амілази в крові поросят контрольної групи була вищою від норми у 2,6 разу, дослідної групи - у 2,38 разу. Порівнюючи активність амілази на 20-у добу згодовування пектиновмісного препарату з 30-ю добою досліджень, встановлено зниження названого показника на 7,6\%.

Різниця між показниками контрольної та дослідної груп статистично невірогідна. Вміст загального білку в крові поросят контрольної й дослідної груп знаходився в межах норми.

Встановлено індивідуальні особливості показників загального білку в крові поросят контрольної групи, а саме, у тварин за номерами №01278; №01178; №01467 вміст загального білку був нижчим від норми, відповідно, на 5,14; 11,$8 ; 1,88 \%$.

Дослідженнями встановлено, що активність трансамінази АсАТ у сироватці крові поросят контрольної та дослідної груп була в межах норми.

\section{2. Біохімічні показники крові поросят (30-а доба досліду), ммоль/л $(M \pm m, n=10)$}

\begin{tabular}{|c|c|c|c|c|c|c|c|c|c|}
\hline \multirow[b]{2}{*}{ Група } & \multicolumn{9}{|c|}{ Показники } \\
\hline & $\begin{array}{c}\text { Зага- } \\
\text { льний } \\
\text { білок, } \\
\text { г/л }\end{array}$ & $\begin{array}{c}\text { Амілаза, } \\
\text { г/г.л }\end{array}$ & $\begin{array}{c}\text { АсАТ, } \\
\text { ммоль/ } \\
\text { г.л }\end{array}$ & $\begin{array}{c}\text { АлАТ, } \\
\text { ммоль/Г.л }\end{array}$ & $\mathrm{Ca}$ & $\mathrm{P}$ & $\mathrm{Na}$ & $\begin{array}{c}\text { Креати- } \\
\text { нін }\end{array}$ & $\begin{array}{c}\text { Сечови- } \\
\text { на }\end{array}$ \\
\hline $\begin{array}{c}\text { Дослід- } \\
\text { на }\end{array}$ & $\begin{array}{c}73,8 \pm \\
3,8\end{array}$ & $\begin{array}{c}83,38 \pm \\
6,45\end{array}$ & $\begin{array}{c}0,95 \pm \\
0,01 * * *\end{array}$ & $\begin{array}{c}1,196 \pm \\
0,02 * * *\end{array}$ & $\begin{array}{c}4,96 \pm \\
0,34 * * *\end{array}$ & $\begin{array}{c}2,39 \pm \\
0,08 * *\end{array}$ & $\begin{array}{c}139,9 \pm 1, \\
83\end{array}$ & $\begin{array}{c}0,138 \pm 0 \\
01\end{array}$ & $\begin{array}{l}3,2 \pm \\
0,34\end{array}$ \\
\hline $\begin{array}{c}\text { Конт- } \\
\text { рольна }\end{array}$ & $\begin{array}{c}61,3 \pm \\
4,7\end{array}$ & $\begin{array}{c}92,42 \pm \\
8,37\end{array}$ & $\begin{array}{c}1,59 \pm \\
0,16\end{array}$ & $\begin{array}{c}1,99 \pm \\
0,19\end{array}$ & $\begin{array}{c}2,68 \pm \\
0,29\end{array}$ & $\begin{array}{c}1,77 \pm \\
0,11\end{array}$ & $\begin{array}{c}138,6 \pm 1, \\
45\end{array}$ & $\begin{array}{c}0,117 \pm 1 \\
7,1\end{array}$ & $\begin{array}{c}1,99 \pm \\
0,15\end{array}$ \\
\hline
\end{tabular}

Примітка: *- $\mathrm{P} \geq 0,95 ;{ }^{*}{ }^{*}-\mathrm{P} \geq 0,99 ;{ }^{* * *}-\mathrm{P} \geq 0,999$ 


\section{ВЕТЕРИНАРНА МЕДИЦИНА}

\section{3. Вміст загального білку і білкових фракцій у сироватці крові поросят (30-а доба досліджень),}

г/л $(M \pm m, n=10)$

\begin{tabular}{|c|c|c|c|c|c|c|}
\hline \multirow{2}{*}{ Група } & \multirow{2}{*}{$\begin{array}{c}\text { Загальний } \\
\text { білок, г/л }\end{array}$} & \multicolumn{2}{|c|}{ Вміст альбумінів } & \multicolumn{2}{|c|}{ Вміст глобулінів } & \multirow{2}{*}{ Г/Г } \\
\cline { 3 - 6 } & $73,8 \pm 3,8$ & $31,7 \pm 2,1$ & $\begin{array}{c}\text { \% до загаль- } \\
\text { ного білку }\end{array}$ & г/л & $\begin{array}{c}\text { \% до загаль- } \\
\text { ного білку }\end{array}$ & \\
\hline Дослідна & $73,99 \pm 1,21$ & $42,1 \pm 2,1$ & $57,00 \pm 1,22$ & $0,76 \pm 0,04$ \\
\hline Контрольна & $61,3 \pm 4,7$ & $29,8 \pm 2,2$ & $47,04 \pm 0,66$ & $31,5 \pm 2,1$ & $52,96 \pm 0,66$ & $0,93 \pm 0,07$ \\
\hline
\end{tabular}

АлАТ в основному концентрується в цитоплазмі, а АсАТ переважно знаходиться в мітохондріях, тобто, глибше запакована в клітині, ніж АлАТ, тому в разі запальних процесів гепатоциту й порушенні проникнення його мембран, передусім у крові збільшується вміст АлАТ, у зв'язку з чим активність в АлАТ у контрольній групі перевищувала норму у 1,3 разу, в дослідній знаходилася в межах норми.

Встановлено, що активність трансаміназ АсАТ і АлАТ у сироватці крові дослідних тварин на 30-у добу досліджень відповідала нормі, про що свідчить коефіцієнт де Рітіса та про припинення дії інгібіторів і активаторів, у ролі яких виступали важкі метали у зв' язку зі зв' язуванням їх пектиновими речовинами і виведенням з організму. Різниця між показниками активності трансаміназ АсАТ і АлАТ контрольної і дослідної груп мав високий рівень вірогідності ( $\mathrm{P}>0,999$ i $\mathrm{P}>0,999)$.

Результати даних таблиці свідчать, що вміст кальцію, фосфору і натрію в крові поросят контрольної та дослідної груп знаходився в межах фізіологічної норми, хоча різниця між показниками вмісту кальцію і фосфору в крові поросят контрольної й дослідної груп мала високий рівень вірогідності (Р>0,999, $\mathrm{P}>0,999)$.

Встановлено, що вміст креатиніну в крові поросят контрольної та дослідної груп на $30-$ д добу досліджень відповідав нормі, становлячи $0,117 \pm 17,1$ та $0,138 \pm 0,01$ ммоль/л відповідно.

Вміст сечовини в крові поросят контрольної

\section{БІБЛІОГРАФІЯ}

1. Виноградов А. П. Биогеохимические провинции и их роль в органической эволюции / А. П. Виноградов // Геохимия. - 1963. - №3. C. $199-212$.

2. Тарасенко Л. О. Санітарно-гігієнічна оцінка дії важких металів на морфологічні структури органів поросят / Л. О. Тарасенко // Науковий вісник Національного університету біоресурсів i природокористування України. - 2013. - Части- групи залишався нижчим відносно норми у 1,5 разу. Відомо, що зменшення концентрації сечовини спостерігається за паренхіматозної жовтяниці, цирозу печінки. Концентрація сечовини в сироватці крові поросят дослідної групи відповідала нормі й становила $3,20 \pm 0,34$ ммоль/л за норми 2,9-8,8 ммоль/л. Різниця між показниками контрольної та дослідної груп статистично невірогідна.

Сполуки важких металів, що накопичуються в органах і тканинах, впливають на процеси обміну в організмі. Тому більш достовірні уявлення про фізіологічний стан організму можна отримати провівши дослідження не тільки загального білку, а й білкових фракцій - альбумінів і глобулінів. Показники вмісту загального білку і білкових фракцій у сироватці крові поросят на 30-у добу досліджень представлено в таблиці 3.

Результати досліджень свідчать, що загальний білок сироватки крові поросят контрольної й дослідної груп на 30-у добу досліджень знаходився в межах фізіологічної норми.

\section{Висновки:}

1. Застосування кормової добавки пектиновмісної впродовж тридцяти діб поросятам сприяло виведенню важких металів (кадмію, свинцю, міді) $з$ організму тварин до рівнів ГДК.

2. Дослідженнями доведено позитивний вплив кормової добавки пектиновмісної на нормалізацію метаболічних процесів, рівень мінерального та білкового обміну, морфологічний склад крові.

на друга. - Серія «Ветеринарна медицина, якість і безпека продукції тваринництва». - С. 174-178.

3. Юраш K. B. Забрудення грунтів важкими металами / К. В. Юраш, Н. І. Драчова // Перлини степового краю: матеріали другої регіон. наук.практ. агроеколог. конф. студентів, аспірантів i молодих вчених (Миколаїв, 4-6 листопада, 2009 р.). - Миколаїв : МДАУ, 2009. - С. 84-87. 